\title{
METAFOR İLE MARKALARI YÖNETMEK
}

\author{
Bilge KARAMEHMET*
}

\begin{abstract}
ÖZET
Her gün binlerce reklam ile karşılaşan tüketicilerin markalar söz konusu olduğunda; zihinlerindeki kavramsal yapılarının sınırlarını aşmak, marka yöneticileri ve reklamcıların beklentisi ve elde etmek istediği sonuçtur. Reklamdaki metaforun gönderdiği mesajların, tüketicilerin deneyimlerinin üzerine eklenerek yepyeni kavramlar üretilecek ve bu sayede tüketicilerin markalara karşı olan bakış açısı üzerine bir anlam daha yüklenecektir. Bu çerçeveden bakıldığında bu çalışmanın amacı; markaların rekabet avantajı sağlayabilmeleri için reklamlarında kullandıkları metafor içerikli söylem veya metafor içeren görsellerin var oldukları her alanda markalara katkı sağlayacağının düşünülmesidir. Bu amaçla her yıl düzenli olarak yapılan Kırmızı Reklam Ödülleri'nde en önemli ödül olan "Kırmızı" ödülünü alan reklamlardaki metaforlar incelenmiştir. Sonuç olarak; ödül alan tüm reklamlarda metaforik dil veya metaforik görsel kullanıldığı kanıtlanmıştır. Ayrıca metaforların markalar tarafından yaygın kullanımına ilişkin ödüllü reklamlar ele alınarak metafor kullanımının yaygınlığı konusunda da dolaylı olarak kanıtlar sunulmuştur. Bu sonuçtan yola çıkılarak markaların tüketicilerin zihinsel süreçlerine dâhil olmaları veya tüketicinin zihinsel süreçlerini yönetebilmeleri adına öneriler sunulmuştur.
\end{abstract}

Anahtar Kelimeler: Pazarlama, Reklam, Metafor, Çağdaş Metafor Teorisi, Marka

\section{MANAGE BRANDS WITH METAPHOR}

\begin{abstract}
When it comes to brands; consumers who encounter thousands of ads every day, the result that brand managers and advertisers want to achieve is beyond the limits of the conceptual structures of consumers' minds. The messages sent by the metaphor in advertising will add new concepts to the consumer's experiences. On this point, there will be more meaning on consumer's point of view towards brand. Its thought to be a great advantage for brands that brands should be involved in the mental processes of consumers in this competitive environment. In this sense this study consider that to contribute the competitive advantage of intended brands when they use metaphorical discourse and metaphorical visuals in their ads it will contribute to the brand. For this purpose, the metaphors in advertisements which received "Red" award which is the most important award Red Advertising Awards which is held regularly every year, has been examined. As a result has been proved that all ads received awards use metaphorical discourse or metaphorical visuals on ads. There is also indirect evidence of the prevelance of metaphor use by brands in awarded ads. From this results, suggestions have been made on behalf of brands to be involved in the mental processes of the consumers or suggestions were presented in order to manage consumer
\end{abstract}

Keywords: Marketing, Advertising, Metaphor, Contemporary Metaphor Theory, Brand

* Yrd. Doç. Dr., İstanbul Medipol Üniversitesi, İletişim Fakültesi, Halkla İlişkiler ve Reklamcillk Bölümü, bkaramehmet@medipol.edu.tr. 


\section{GíRiş}

Sosyal hayatımızda metaforların varlığından çok haberdar olmasak da metaforun Aristoteles'ten bu yana kullanıldığı bilinmektedir. Geçmişte retorik amaçlarla kullanılan metafor günümüzde iletişimin her alanında hatta iletişimin hemen hemen her biçiminde kullanılmakta ve sosyal bilimlerin birçok alanında konu edildiği görülmektedir.. Bu gerçekten hareketle, bu çalışmada metaforun pazarlama alanındaki kullanımlarına tüketici zihinlerine dahil olma konusu çerçevesinde değerlendirmeler yapılmıştır. Bu değerlendirmeler her yıl düzenli olarak gerçekleştirilen Kırmızı Reklam Ödülleri baz alınarak, ödüllü reklamlar üzerinden içerik analizi yoluyla değerlendirmeye tabi tutulmuştur. Çalışmada metaforun tanımı, kapsamı ve türleri öncelikle ele alınmıştır. Literatür incelemesi yapılarak Çağdaş Metafor Teorisi konusu yapılan çalışmalar üzerinden aktarılmıştır. Ardından Kırmızı Reklam Ödülleri’nde ödül alan reklamlar metafor analizine tabi tutularak, metafor kullanımı ile ilgili öneriler sunulmuştur. Bu haliyle hem marka yöneticilerine öneriler sunulmuş, hem de reklamveren ve reklam ajanslarının yalnızca ödül alma amaçlı değil, tüketicilerin karar verme süreçlerine de dahil olabilecekleri gerçeği üzerinde durulmuştur.

\section{METAFOR VE TÜRLERİ}

\section{Metafor}

Aristoteles'ten bu yana iletişim alanında çalışan kuramcılar, metaforların düz söylemden nasıl farklılaştı̆ğını, alıcıların metaforları nasıl algılayıp anladıklarını, metaforları nasıl değerlendirdiklerini ve dilbilimde nasıl bir etkisi olduğunu anlamak adına birçok araştırma ve analiz yapmışlardır.

Metaforun tanımını yapmak gerekirse; metafor bilinmeyen herhangi bir şeyi bilinen herhangi bir şey açısından ifade etmek anlamına gelmektedir. Ayrıca metafor bilinmeyenin anlamını, bilinenin araçları ile ortaya koyma olarak da ifade edilebilir. Dikkat edilmesi gereken en önemli noktanın aynı paradigmada olabilmek adına araç ve anlamların yeterli benzerliğe ve gerekli karşılaştırmayı yapabilmek için yeterli farklılığa sahip olması gerekmektedir (Erdem ve Sarvan, 2001).

Gerald ve Zaltman'ın metafor konusunda yaptığı araştırmalarda dünyanın birçok yerinde, çoğu kültürde ve çoğu toplumda insanların; bizim tahmin ettiğimizden çok daha fazla birbirlerine benzeyen zihinsel kalıplarla hareket ettiklerini açıklıkla ortaya koymaktadırlar (Pink, 1998). Yaptıkları araştırmada dünyanın hemen her yerinde insanların benzetme ve metaforları aynı şekilde kullanarak kendilerini ifade etmektedirler. Bu açıdan bakıldığında markaların kendilerini tüketicilere sunarken kullandıkları ya da kullanacakları dilin önemi ortaya çıkmaktadır. Markalar tüketicilere ulaşırken kullandıkları dil, tüketicilerin bilinçdışı süreçlerini ortaya çıkardığı 
gerçeğini unutmamaları gerekmektedir. Markayı doğru yönetmenin tüketici zihnindeki metaforları algılamaktan geçtiği açıktır.

Bu kapsamda kuramcılar psikoloji, anlambilim ve pragmatizm disiplinleri ile geliştirilmiş; birçok çalışma ile karşılaşmışlardır (Gibbs, 1999: 29).

Metafor Yunanca "Metaphrein" ya da "Metafora" köklerinden türemiş̦tir. "Meta"değiştirme, "phrein" ise taşımak anlamındadır. (Levine, 2005: 172-175).

"Metaphors We Live By" adlı eserde metaforun dilbilimsel bir fenomenden öte gündelik yaşamda düşünce ve eylemlerimizi yönlendiren kavramsal sistemimizin temelini oluşturduğu öne sürülmüştür. "Düşündüğümüz ve uyguladığımız şekliyle sıradan kavramsal sistemimiz, esas itibarıyla doğası gereği metaforiktir " (Lakoff ve Johnson, 1980: 3).

Lodge, düzdeğişmece ve kapsamlayışı dilin birleşim eksenine konumlandırırken metaforu dilin seçme eksenine yerleştirir (Lodge, 2003: 66). Forceville (1996: 35) görsel metaforu beklenen bir görsel öğenin beklenmedik bir görsel öğeyle değiştirilmesi olarak tanımlamıştır.

Jakobson, konuşma ve yazma eyleminin temeline yerleştirdiği metafor ve düzdeğişmeceyi edebiyatın ötesinde sinema ve resim gibi farklı gösterge sistemlerinin merkezine de örnekleriyle konumlandırmıştır (Jakobson, 2003: 77).

Görsel metaforlar hakkında temel nitelikte bazı araştırmalar yapılmış olsa dahi (Carroll, 1999; Forceville, 1996) görsel metaforların nasıl anlaşılması gerektiği ve sözlü metaforlardan nasıl ayrıldığ 1 hakkında tartışmalar günümüzde de devam etmektedir. Metaforlara bilişsel bir fenomen olarak bakılmas1 1980'lerin başında popüler olmuştur (Gibbs, 1999; Lakoff ve Johnson, 1980). Sonuçta, birçok yazar metaforların yazılı şekil dışında farklı şekillerde de temsil edildiğini göz ardı etmiştir (Refaie, 2003: 76).

Seitz'e göre bu durumun aksine bilişsel kuramcılar, metaforun düşüncenin bir parçası olduğunu ve bunun bir çeşit şeyin farklı bir şeye dayanarak anlaşılması ve tecrübe edilmesiyle ilgili olduğunu öne sürmüşlerdir. Bu nedenle, iletişimin herhangi bir çeşidi, metaforik düşünce veya kavrama sebep olabiliyorsa metafora örnek olarak gösterilebilmektedir. Metaforun sadece dilbilimsel değil, bilişsel bir fenomen olarak görülmesi artık birçok etkili deneysel çalışmayla da desteklenmektedir (Seitz, 1998: 85).

Metaforların eğitimsel ve açıklayıcı araçlar olarak kullanılmalarında kuşkusuz ki bazı sinırlılıklar ve sakıncalar bulunmaktadır. Belirli bazı metaforlar bizim kurduğumuz bağlantılar olduğu kadar bizim kurmadığımız veya aklımıza gelmeyen bağlantıları da etkilemektedirler. Böylece de metaforlar "düşüncenin önünü kesebilirler ve sadece belirli bir düşünce kalıbının içerisine kilitleyebilirler (Arslan ve Bayrakc1, 2006:100-108). Bu açıdan bakıldığında çalışmanın ilerleyen aşamalarında da detaylarıyla incelenecek olan metaforlar üzerinden insanların zihinlerini yönetme- 
nin mümkün olabileceği görülecektir. Tüketicinin geçmiş deneyimleri, satın alma geçmişi, ürüne ya da markaya karşı tutumu veya davranışı ve hatta algısı metaforlar yoluyla değiştirilebilir.

Konuya bu çerçeveden bakıldığında metafor kavramının sosyal bilimlerde; ticarette, marka imajı belirlemede, marka algısı oluşturma çalışmalarında, tüketicilerin zihinsel süreçlerini anlamada ve yönlendirmede ve hatta pazarlama araştırmalarında da kullanılabileceği gerçeği ile karşılaşılmaktadır.

\section{Metafor Türleri}

Metafor konusu ele alındığında metafor türlerinin neler olduğu önem kazanmaktadır. Göstergebilimde kullanılan metafor türlerinin neler olduğuna ilişkin farklı ayrımlar söz konusudur.

Chandra (2009)'nın çalışmasında belirttiği 18 metafor türü vardır. Bunlar; Genişletilmiş veya teleskop metafor, Metonym, Karışık metafor, Mutlak metafor, İmalı metafor, Ölü metafor, Zamanaşımı metafor, Synecdoche metafor, Kök metafor, Aktif metafor, Batık metafor, Metafor Dying, Kavramsal metafor, Pataphor, Basit veya Sıkı metafor, Örtülü metafor, Bileşik veya Gevşek metafor, Kompleks metafordur

Northquist (2017)' in çalışmasında 13 metafor türünün olduğunu belirtmiştir. Bunlar; Mutlak Metafor, Kompleks Metafor, Kavramsal Metafor, Konvansiyonel Metafor, Yaratıcı Metafor, Ölü Metafor, Genişletilmiş Metafor, Karışık Metafor, Sezgisel Metafor, Kök Metafor, Batık Metafor, Terapötik Metafor ve Görsel Metafordur.

Bu metafor türleri bazen birbirlerinin içine geçmiş bazen de birlikte kullanılan metafor türleri şeklinde karşımıza çıkmaktadır. Bu durumda genel bir ayrımın yapılması söz konusu değildir. Genel olarak metafor türleri incelendiğinde 8 metafor türünün öne çıktığı görülmüştür.

\section{1. Ölü Metaforlar}

Yeni bir terimin oluşumunda metafor ve düzdeğişmece genellikle ilk aşama olarak görülür. Zamanla bir metaforun kökenleri unutulabilir ve o ifade dilin kabul edilmiş, benimsenmiş bir parçası haline gelir. Bu işlemi özümseme olarak adlandırırken, metaforu da «ölü metafor' olarak adlandırırız.

"Masanın ayă̆l, meselenin özü, politikanın nabzl, dağın eteği, içi acımak, içine sindirememek $v$ b. gibi metaforlar, öylesine uzun zamandır kulanılagelmiş ve öylesine sıradanlaşmışlardır ki benzeyenle benzetilen (taşıyıcı) arasındaki çakışmazlığın farkına varamayız" (Salman, 2003: 53).

Başka bir ifade ile; Steven Johnson (1997: 87), ölü metaforları anlatırken Derrida'nın "White Mythologies" yapıtında kullandığı benzeşime atıfta bulunur: 
“... Bir kitabı 'pırıltıll' olarak tanımlarken güneş ışığını mı düşünürüz? Bir analog saatin kollarını düşünürken elleri ve parmakları mı hayal ederiz? Kavramların benzerlikleri sözbilimsel değerlerini silip, yok etmiştir, tıpkı kullanımdan dolayı yüzü yıpranan ve mevcut değerinden basit bir metale dönüşen bir bozuk para gibi..."

Bir metafor, metaforik anlamı sözlüğe yerleştiği andan itibaren ölü olarak varsayılabileceği (Condon, 1999:10) gibi “ölü”, "ölü ve gömülmüş", "uyuyan” ve "yorgun" olarak ayırdığı bir sınıflandırma (Goatly, 1997: 31) da yapılabilir. Bunun yanında "metafor değildir" denilen ölü metaforun metaforik kullanıma gebe olduğu (Black, 1993) savunulurken, metafor; sözlüklerdeki mezarlıklar olarak da nitelendirilmiş̧ir (Condon, 1999).

\section{2. Kapalı Metafor}

Kapalı metafor türünde, benzeyen açıkça belirtilmez, yalnızca çağrıştırılır, anımsanması sağlanır. Kendisine benzetilenin açıç̧a yer almadı̆̆ı, onu hatırlatan veya onunla ilgili bir unsurun bulunduğu bir metafor türüdür (Çınar, 2008: 132)

\section{3. Karma Metafor}

Karma metafor türünde, iki ya da daha fazla sayıda farklı benzetilen (taşıyıcı) birleştirilir. Ya da bazen iç içe geçirilir. Sheakespeare gibi, söz sanatlarını çok yoğun kullanan şairlerde bu tür metafor kullanımlarına sık rastlanmaktadır (Filizok, 2001).

\section{4. Soyut ve Somut Metaforlar}

$\mathrm{Bu}$ metafor türü bir kavramın ya da kavramlar arasındaki karşılaştırmanın direkt olarak tecrübe edilmesi yoluyla somut ve soyut metafor olarak birbirinden ayrilmaktadır (Morgan ve Reichert, 1999:2).

Soyut metaforlar, doğrudan tecrübe edilemeyen, elle tutulamayan ve maddi olmayan karşılaştırmaları kapsamaktadır. Soyut metaforlar pazarlama bakış açısıyla bakıldığında; markanın ürünü ya da hizmeti ile maddi olmayan diğer bir kalite arasında yapılan bir karşılaştırma olarak tanımlamak mümkündür (Morgan ve Reichert, 1999: 2). Bir imajın, bir simgenin ya da bir markanın uyandırdığı deneyimler arasındaki bir karş1laştırma, doğrudan tecrübe edilen gerçek bir nesnenin ortaya koyabileceği bir karşılaştırmadan farklıdır. Bu durum soyut metaforların varlığını ve geçerliliğini ortadan kaldırmamaktadır (Morgan ve Reichert, 1999: 2).

Percy ve Rossiter (1992: 263-274), somut kelimelerin ve ifadelerin, genellikle, soyut olanlara nazaran daha anlamlı ve daha kolay anlaş1lır olduğu sonucuna varmıştır. 


\section{5. Kavramsal Metafor}

Kavramsal metaforlar soyut fikirlerdir. Günümüzde çağdaş metafor teorisine bağl1 olarak yapılan sinıflamaya göre temelde üç tür metafor vardır: Kavramsal (conceptual) metafor, varlıksal (ontological) metafor, yön (orientational) metaforu (Lakoff, 1993). Konuyla ilgili detaylı açıklamalar bir sonraki bölümde yer alacaktır.

Kavramsal metafor türü source domain (kaynak kavram alanı) ve target domain ( hedef kavram alanı) olarak iki kavram alanından oluşmaktadır. Hedef kavram alanının izleyici ya da dinleyici veya hedef kitle tarafından anlaşılabilmesi için kaynak kavram alanının mutlaka anlaşılması gereklidir. Buradaki en önemli husus kaynak kavram alanının somut bir kavramdan oluşması hedef kavram alanının soyut veya fiziksel bir kavram veya somut olabileceğidir (Akşehirli, 2005).

\section{3. Çağdaş Metafor Teorisi Kapsamında Metafor Türleri}

\subsection{Yapı Metaforları}

Bir kavramın farklı yapıya kavuşmasına yapı metaforları denir. Yapı metaforlarının kültürel özellikleri olabildiği gibi evrensel özellikleri de bulunmaktadır (Şeyihoğlu ve Gençer, 2011). Lakoff ve Johnson; yapı metaforlarını tanımlamak için "tartışma savaştır" metaforu incelendiğinde bağlayıcı kuralları olmayan bir tartışmada her ne olursa olsun sahip olunan her sözlü aracı - gözdağı verme, tehdit etme, otoriteye müracaat etme, hakaret etme, küçümseme, otoriteye meydan okuma, konudan kaçma, pazarlık, poh pohlama ve hatta rasyonel nedenler vermeyi deneme, kendi lehine kullanarak saldııır, savunur, karşı saldırıya geçer vb. şeklinde ifade etmiştir (Lakoff ve Johnson, 2005:36).

\subsection{Yönelim- Yön Metaforları}

Yönelim metaforlarının, yönelim olarak adlandırılmasının nedeni, uzay ve mekân doğrultusuyla ilişkili olmalarındandır. Yukarı-aşağı, içeri-dışarı, beri- öte, derin-satıh, merkez-çevre gibi. Bu uzay ve mekan yönelimleri, sahip olduğumuz türde bedenlere sahip olmamızda ve bedenlerimizin fiziksel çevrede fonksiyon icra ettiği gibi fonksiyon icra etmesinden doğar. Yönelim metaforları bir kavrama uzay ve mekan yönelimi verir, sözün gelişi; MUTLU OLAN YUKARIDADIR. MUTLU kavramını YUKARI (UP) yönelimli olması "Kendimi bugün yukarıda ( iyi, hafif ) hissediyorum" benzeri ifadelere yol açar. Bunun gibi metaforik yönelimler keyfi değildir. Onların fiziksel ve kültürel tecrübelerimizde bir temeli vardır. Yukarı- aşağ1, içeri- dışarı vb. karşıt yönelimler doğada fiziki olsa da, onlara dayanan yönelim metaforları kültürden kültüre değişebilir (Lakoff ve Johnson, 2005: 36). 


\subsection{Ontolojik Metaforlar}

Ontolojik metaforlar, bireyin yaşantılarındaki soyut kavramları, daha belirgin ve daha somut biçime dönüştürmede kullanılırlar. Birey; soyut kavramları, fiziksel nesnelere dönüştürerek onlar hakkında konuşabilir, sınıflandırabilir ve bütün bunların sonucunda onlar hakkında düşünebilir duruma gelir (Akşehirli, 2005). Kişileştirme; Ontolojik metaforların insan dışı varlıklara ve olgulara imgesel yolla insan özellikleri kazandıran türüne kişileştirme adı verilmektedir. Örneğin; ENFLASYON BİR DÜŞMANDIR (Lakoff ve Johnson, 2005:58). Metonomi; esas olarak bir referans işlevine sahiptir. Başka bir deyişle, bir şeyin diğerinin yerine geçecek biçimde kullanılmasına olanak sağlamaktadır. Referans aracı olma özelliğinin yanı sıra, metonominin anlamı sağlama amacı da bulunmaktadır. Metonomi atıfta bulunulan şeyin kimi niteliklerine özellikle odaklanılmasını sağlamaktadır. Kavram sisteminde "bütün yerine parça metonomisi” özel bir konuma sahiptir. Örneğin; üniversitede pek çok iyi kafa var. (=zeki insanlar) (Lakoff ve Johnson, 2005:61).

\section{Araştırma Yöntemi ve Ödül Alan Reklamlarda Kullanılan Metaforlar}

Nitel araştırmalar, ürünlerden ya da çıktılardan daha çok süreç ile ilgilenmektedir. Dolayısıyla nitel araştırmalarda anlamlar önem taşımaktadır (Altunay, vd. 2014). Doküman inceleme yoluyla gerçekleştirilen araştırmada daha önce de belirtildiği üzere Kırmızı Reklam Ödülleri'nde ödül alan reklamların incelenmesi yoluyla metafor değerlendirmesi yapılmıştır.

Metaforlar önemli ve tartışmalı konular söz konusu olduğunda tartışmayı genele yayarak insanların konuyla ilgili düşüncelerini etkileyebilir (Thibodeau, 2016: 5372), zengin bakış açıları geliştirilmesine yardımcı olabilirler.

Zengin bakış açıları geliştiren metaforlar aynı zamanda görme biçimlerinde de yenilik getirmiştir (Koro-Ljungberg, 2001: 367-379).

Birçok metafor zihinsel simgelerdir ve bunların büyük bir çoğunluğu görseldir(Kosslyn et al., 1990). Zaltman Metafor Çıkarım Tekniği (Zaltman Metaphor Elicitation Technique) (Coulter ve Zaltman, 1994) (ZMET) adiyla niteliksel bir teknik geliştirilmiştir. Geliştirilen bu teknik ile pazarlama karması (4P) ile segmentasyon kararlarını, tüketicilerin düşünce ve davranışlarını yönlendiren metaforlara bakılarak analiz etme imkanı sunmaktadır.

Görüntülerin değerlendirilmesi ve reklam, pazarlama ve tüketici araştırmaları arasındaki ilişkiyi açıklayan pek çok kaynak vardır. (bkz. Lutz ve Lutz, 1978: 611-620; Rossiter 1982; Rossiter ve Percy, 1978: 263-274; MacInnis ve Price, 1987: 41-47; Bone ve Ellen, 1992: 93-104) detaylı olarak incelenebilir.

Müşteri ve Firma Metaforları: Marka ile ilgili metaforları müşterilerin nasıl anla- 
dığını ve bu metaforların reklam ajansı veya bunu üreten firmanın nasıl etkileşim halinde olduğunu anlamak oldukça önem arz etmektedir. Bir marka ile ilgili metaforlar; görsel, sözel, matematiksel ve müzikal olabilen diğer yapılar arasında yer alabilmektedir. Bu görüntüler müşteri deneyimleri, müşteri anlayışını, kısa bilgileri, paketleme bilgilerini, markanın nerede satılabileceği ve reklam kampanyası hakkındaki bilgileri içerir.

Biel (1993: 67-82) markaları düşündüğümüzde görsel sunumların sıklıkla akla geldiğini savunmaktadır. Bu durum özellikle tanınmış markalar için geçerlidir. Örneğin Mc Donalds markasının M harfi göründüğünde hemen Mc Donalds markası akla gelmektedir. Fakat daha az tanınmış markalar için aynı şey söz konusu değildir. Bir firmanın veya reklam ajansının bir marka ile ilgili metaforları, reklam, ürün ve ambalaj tasarımı, ürün konseptleri ve dağıtım kanalları gibi çeşitli pazarlama karması kararları biçiminde iletildiğinden, bu metaforların hem müşterilerinin zihninde marka için oluşturdukları metaforlarına benzeyen hem de benzeri olmayan bileşenleri içermesi gerekir. Müşterilerin kendilerine yatkın olan metaforlarını reklamcılıkta, bir ürünün tasarımında veya bir mağaza düzenlemesinde benzerlikler bulması önemlidir. Bu yüzden müşteri tarafindan oluşturulan görüntülerle uyumlu olan bir pazarlama iletişimi; müşterilerin daha fazla katılmaya ve anlamaya elverişli olduğu bir ortam yarattığı düşünülmektedir. Diğer bir taraftan bakıldığında ise farklılıkların gerekli olduğu görülmektedir. Böyle bir durumda, dikkat çeken ve mesajın anlaşılmasının temelini oluşturan bir miktar gerilim yaratırlar. Asıl bu noktada yaratıcı yazarlar veya görsel tasarım yapan profesyoneller ve ürün tasarımı personeli, yaratıcı "farklılıklar" bileşenini sağlamada çok önemli bir rol oynamaktadır.

Metafor olarak Resimler ve Temel Kavramlar: Çoğu iletişimin sözsüz iletişimden oluştuğu bir gerçektir. Resimler diğer müşterilerin kavramlarını keşfetmek için giriş noktaları olarak hizmet edebilirler (Weisner 1988: 237-270; Ball and Smith 1992). Resimler genelde kapsamlı bilgi içeren veya nitelikleri tanımlayan temel kavramları temsil eder ve insanlar genellikle bu tür kavramları önce tanırlar. Müssteriler temel kavramları tanımladıktan sonra ilişkili daha üst düzey kavramları çıkarabilir veya tespit edebilirler (Rosch 1978: 27-48). Örneğin, "Hershey öpücüğ̈̈” kavram1, üst düzey "çikolata" kavramından daha belirleyici özelliklere sahiptir. "Hershey öpücüğ̈̈" kavramı çikolata kavramından daha fazla bilgi içerir, daha kolay tanınır ve "çikolata" kavramından ziyade bilgi aktarmaya başlamanın daha etkili bir yoludur. Resimler çok basit, bilgi açısından zengin ve özellik yüklü olduklarından, çoklu ilişkili daha üst düzey yapılarla ilişkilendirilebilirler. Resimler, müşterilerin yüksek mertebeden yapıları iletmeye başlaması için doğal ve etkili bir yoldur. Aslında bazı klinik psikologlar terapötik danışma sürecinin merkezi bir parçası olarak bir müşterinin fotoğraflarını kullanıyorlar (Entin 1981; Krauss ve Fryrear 1983; Weisner 1988: 237-270).

Metafor anlaşılma ya da yeniden yapılanma ihtiyacı olan bir etki alanı içine tanıdık alan deneyimlerine ait açıklayıcı yapıları taşıyarak yapısal benzerlikleri görünür 
hale getirir ve böylece hedef alan için herhangi bir yapısal benzerliğin çok ötesinde bir organizasyon sağlanmış olur (Krippenendroff, 1993; Lakoff ve Johnson,1980). Böylece yeni veya karmaşık bir kavram, olgu veya olay; bilinen daha basit kavram, olgu veya olay ile açıklanmaya çalışılır (Güneş ve Fırat, 2016: 115-129).

Metaforun araştırmalarda kullanılması ve metodolojik olarak çalışılması (Miller, 1987: 219-227; Koro-Ljungberg, 2001: 367-379; Phillips ve Hardy, 2002; Schmitt, 2005: 358-394) markalara çok yönlü bakış açısı sunması açısından da önem arz etmektedir.

Çok kültürlülük ve pazar çevresinin küreselleşmesiyle ortaya çıkan kültürel karmaşıklık nedeniyle pazarı ve tüketici davranışını daha iyi anlamak için pazarlama düşüncesindeki temel görüşlere eleştiri getirilmesine ve bilinen pazarlama ve tüketici araştırmaları yöntemlerinin yetersizliği gündeme gelmektedir (Torlak, 2008: 65; Moisander ve Valtonen, 2006: 3-4 ). Özetle tüketici davranışlarını anlamada nitel araştırma yöntemlerinin kullanılması daha gerekli hale gelmiştir. Metafor aracılığılla analiz yapmak ve elde edilen verilerden ortaya çıkan metaforları tüketicilerin kendi kültürel değerleri içinde anlamaya ve anlamlandırmaya çalışmak daha doğru bir yoldur (Moisander ve Valtonen, 2006: 128-129).

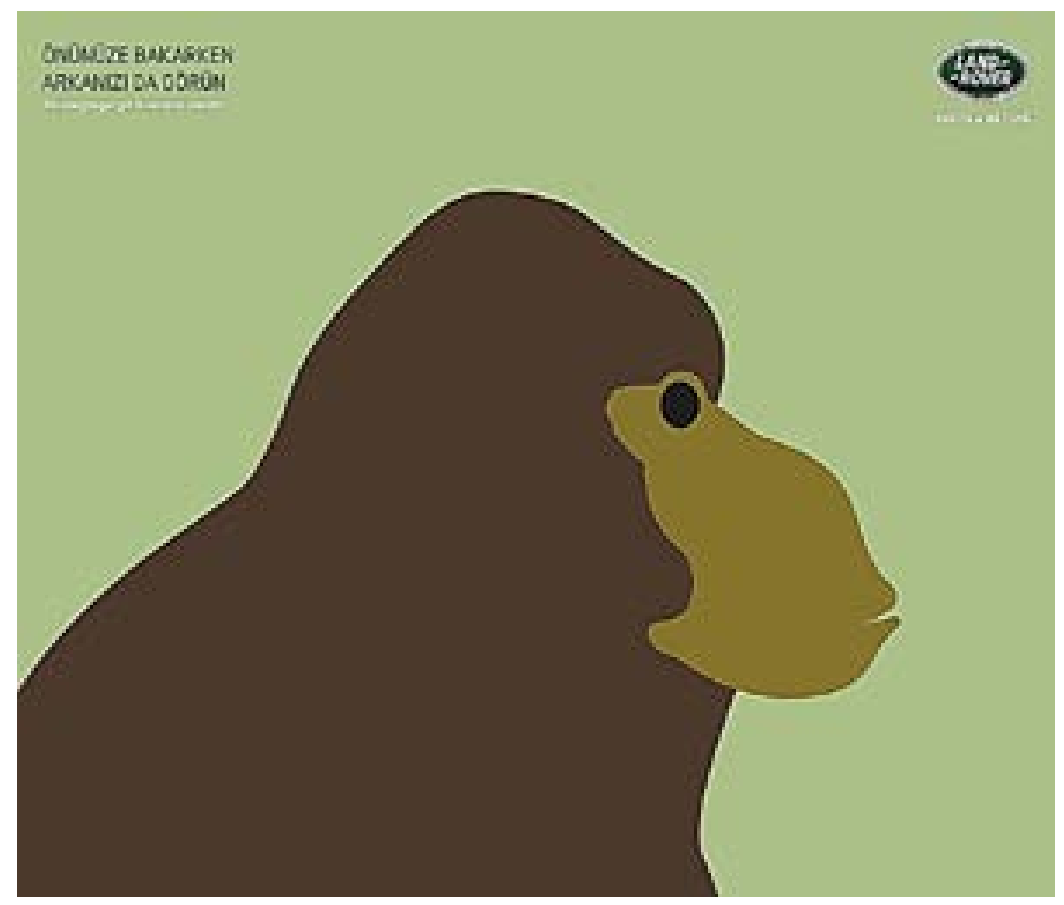

Fotoğraf 1. Land Rover Reklamı

Reklama bakıldığında; Land Rover markasının reklamı olduğu görülmektedir. Ödül alan bu reklamın metin kısmı incelendiğinde; "Önünüze bakarken arkanızı da görün", "Discovery'de geri görüş kamerası standart." anlatımını görmekteyiz. 
Reklam İncelemesi: Önünüze bakarken arkanızı da görün

Ön ve arka kelimelerinin yer alması dolayısıyla yön metaforunun kullanıldığı açıktır. Aynı zamanda Discovery adlı markada geri görüş kamerasının standart olduğu ifade edilmektedir. Bu durumda "geri görüş̧" ifadesinde de yön metaforunun kullanıldığını görülmektedir.

Reklam görseline bakıldığında ise maymun ve kurbağa karakterinin birlikte kullanıldığı görülmektedir. Bu durumda ontolojik metaforun kullanıldığı açıktır. Otomobil kamerası maymun ve kurbağa yerine kullanılmış, bir tane göz bebeği noktası ile iki varlık temsil edilmiştir. Genel bir değerlendirme yapılırsa, reklamda hem yön hem de ontolojik metafor kullanılmıştır. Bu kullanım ile hem görsel açıdan metafor kullanılmış hem de dilbilimsel açıdan metafor kullanılmıştır. İzleyici üzerinde hem görsel hem de düşünsel açıdan etkili olduğu düşünülmektedir. Otomobilde tüketicinin beklentisi olan güvenlik konusunda; Land Rover markasının varlığını belirttiği görülmektedir. Ayrıca çarpıcı bir reklam olarak da değerlendirilebilecek Land Rover reklamı tüketicileri güvenlik ve geniş açılı görüş kavramlarına çekmeye çalışmaktadır. Bu çerçeveden bakıldığında Land Rover markasının reklamında metafor yoluyla tüketici zihnine dahil olduğu açıkça görülmektedir.

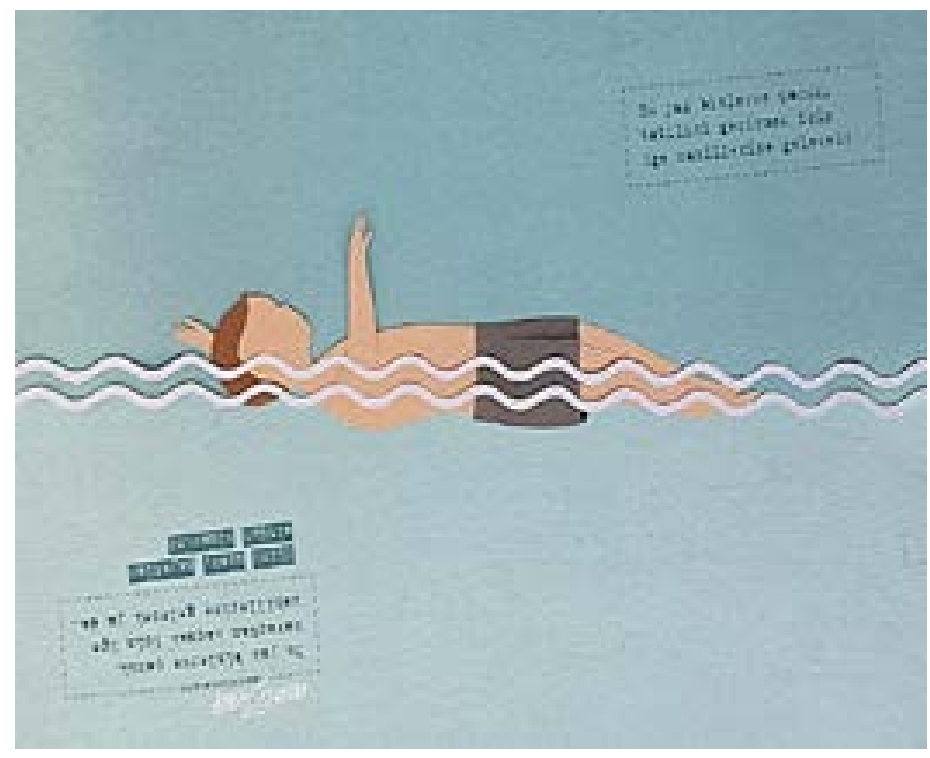

Fotoğraf 2. Dost Eller Reklamı

Dost eller reklam afişi incelendiğinde; "Bu yaz binlerce çocuk, tatilini geçirmek için Ege sahillerine gelecek" reklam metni çift taraflı olarak yer almaktadır. Reklam görseline ülkede yaşanan mülteci krizi göz önüne alınarak değerlendirilmelidir. $\mathrm{Bu}$ anlamda incelendiğinde; mültecilerin yasa dışı göçleri sırasında yaşanan çocuk ölümlerine dikkat çekilmektedir. Bu yargıya reklam görselini alt üst ettiğimizde varabiliyoruz. Bir taraftan yüzen çocuk görseli olarak algılanırken diğer taraftan 
ölmüş ve su yüzünde görünen bir çocuk olarak algılanmaktadır. Bu anlamda bakıldığında reklam görselinde yapı metaforu kullanılmıştır.

Dost eller toplumsal içerikli bir reklam ile karşımıza çıkmaktadır. Son dönemlerde ülkemizde yaşanan güncel olaylar göz önüne alındığında izleyicilerin algıları zaten bu konuya açik olduğu tahmin edilmektedir. Dost eller reklamı, bu durumu lehine kullanıp farkındalık yaratmaya çalışılmaktadır. Böylece izleyicilerin zihinsel süreçlerine dahil olup konunun her iki açıdan da değerlendirilmesi sağlanacaktır.

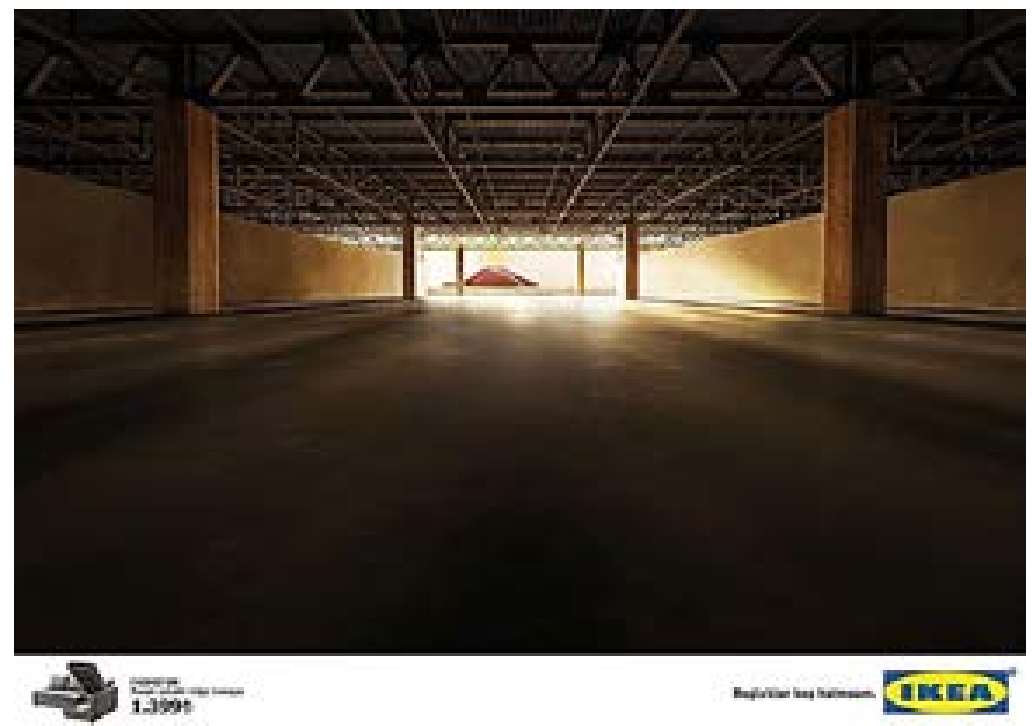

Fotoğraf 3. Ikea Marka Reklamı

Ikea markasının reklam görselinde büyük ve boş bir alan bulunmaktadır. Bu alanın kanepe içini temsil ettiği reklam metni alanındaki "Bazalı yataklı köşe kanepe" metinden çıkarılmaktadır. Kanepenin baza kısmı büyük bir alan olan bir depoya benzetilmiştir. Bu durumda yapı metaforunun kullanıldığı açıktır. Ferahlık ve geniş alan tüketicilerin mimari açıdan görmek isteyecekleri alanı reklam görselinde sunmaktadır. Bunun yanında IKEA markası genişlik kavramının algısını tüketici zihninde daha da çarpıcı bir hale getirmek için baza reklamı ile tüketici karşısına çıkmıştır. Ikea markası bilindiği üzere küçük alanlarda büyük yaşam alanları oluşturduğunu iddia eden bir markadır. Markanın bu iddiası üzerine baza üzerinden metafor kullanarak tüketicilerin bu konudaki zihinsel algılarını pekiştirmek istemiştir. Ayrıca reklam görselinde de görüleceği üzere; baza olarak bilinen kanepe altı saklama alanı, tüketicilerin en çok kullandıkları ve özellikle ek eşyaların muhafaza edildiği alandır. $\mathrm{Bu}$ açıdan bakıldığında insanların oldukça ihtiyaç duydukları saklama alanlarının genişliği metafor yoluyla tüketiciye aktarılmıştır. Ikea markası metafor kullanarak tüketicilerin zihinsel süreçlerine bu anlamda dahil olacak, ardından eğer ölçülürse; gelen tepkiler üzerinden bu zihinsel karar verme süreci marka yöneticileri tarafindan oldukça etkin bir şekilde yönetilebilecektir. 


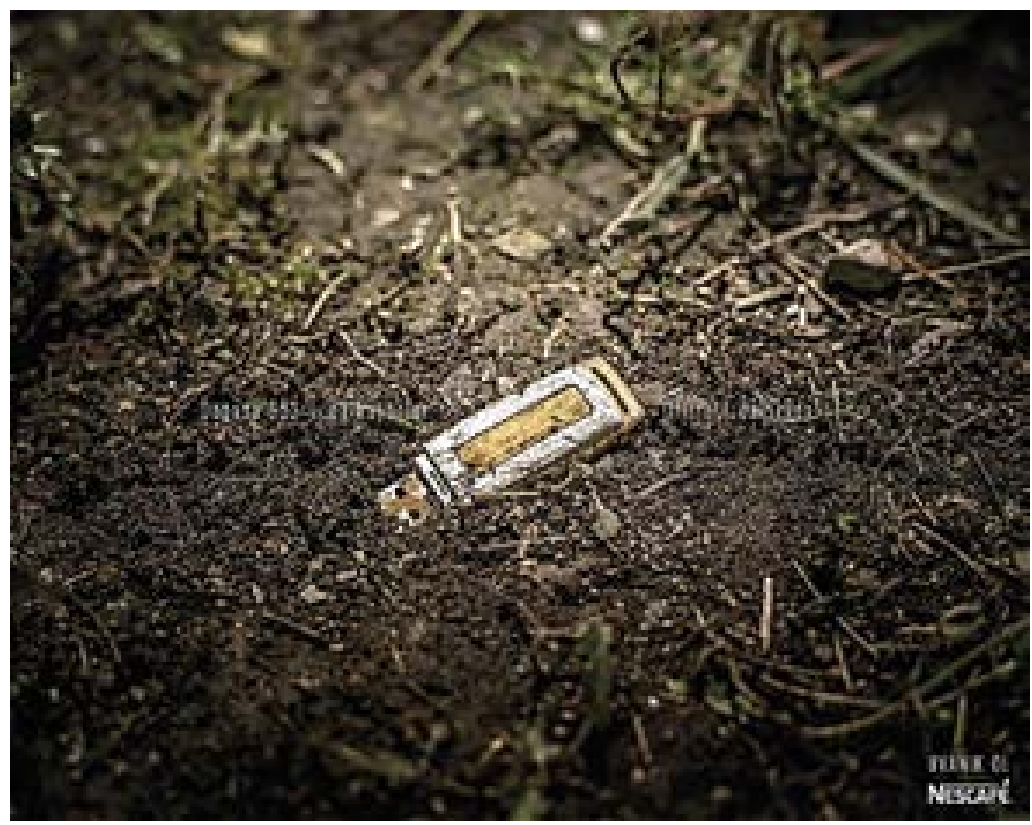

Fotoğraf 4. Nescafe Marka Reklamı

Nescafe markasının reklamı incelendiğinde; "Doğada 953 yılda kaybolur Ofiste 1 dakikada" metni yer almaktadır. Metinde taşınabilir belleğin kaybolması söylemi objenin kişileştirilmesi yoluyla ontolojik metafor kullanılmıştır.

Nescafe marka reklamı görsel açıdan incelendiğinde; Nescafe markasının sosyal içerikli bir reklam ile tüketicinin karşısına çıktığı görülmektedir. Görsel açıdan; toprakta yer alan taşınabilir bellek doğada çözünüp yok olan ürünler için kullanılan bir ürün yerine de kullanılarak da metafor kullanılmıştır. Reklamında hem görsel hem de dilbilimsel açıdan metafor kullanan Nescafe markası çevre bilincini hatırlatan bir reklam yapmıştır. Ayrıca reklamda herhangi bir ürünün ya da nesnenin yok olması veya kaybolması ile iş hayatındaki yaşam alanlarından olan ofiste kaybolması arasında bir bağlantı kurmuş, aralarındaki farkı mizahi bir dil kullanarak tüketiciye aktarmıştır. Böylece izleyici ya da tüketicinin karşısına hem mizahi içeriği ile dikkat çeken bir reklam ile hem de sosyal farkındalığı olan bir reklam ile çıkacaktır.

Nescafe markasının bu reklamda asıl anlatmak istediği veya asıl aktarmak istediği mesajın tüketicinin sürekli uyanık olması için nescafe içmesi gerektiği mesajıdır. Bu mesajı hem görsel hem de dilbilimsel açıdan değerlendirip tüketici zihinsel sürecine dahil olmaya çalışmaktadır. Eğer reklam sonrası tüketici tepkisi ölçülürse reklamın ne denli etkili olduğu ve tüketici zihinsel karar verme sürecinin içerisine girebilme imkanı ve hatta marka yöneticilerinin tüketici zihinsel karar verme süreçlerini yönetebilme şansı doğabilecektir. 


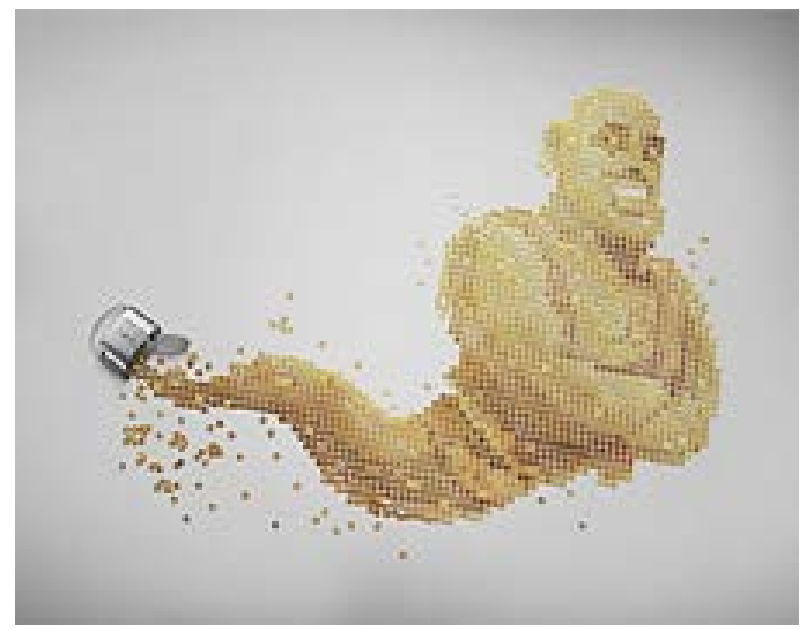

Fotoğraf 5. İş Bankası Reklamı

Ödül alan İş Bankası reklamı incelendiğinde; İş Bankası kumbarası Alaaddin'in sihirli lambasına benzetilmiş, lamba içerisinden paradan oluşan bir masal karakteri olan lamba cini görünümlü bir görsel bulunmaktadır. Reklam görseline detaylı olarak bakıldığında yapı metaforunun kullanıldığı, İş Bankası kumbarası ile birçok isteğin yerine getirilebileceği ifade edilmeye çalışılmıştır. Bu açıdan incelendiğinde paralardan oluşan görselin insana benzetildiği ve bu anlamda ontolojik metafor türünün kullanıldığı açıktır. İş Bankası markasının reklamı farklı bir bakış açısıyla incelendiğinde ise İş Bankası aracilığıla isteklerin gerçek olabileceği mesajının verildiği fark edilmektedir. Bu haliyle İş Bankası ile çalışan kişilerin veya kurumların isteklerinin banka tarafından karşılanacağı varsayımı, dolaylı yoldan anlatılmıştır. Marka yöneticileri tüketicilerin reklamı gördüğünde yaşadıkları düşünsel karar verme sürecini paradan oluşan lamba cini ile yönetme imkanı bulacakları düşünülmektedir.

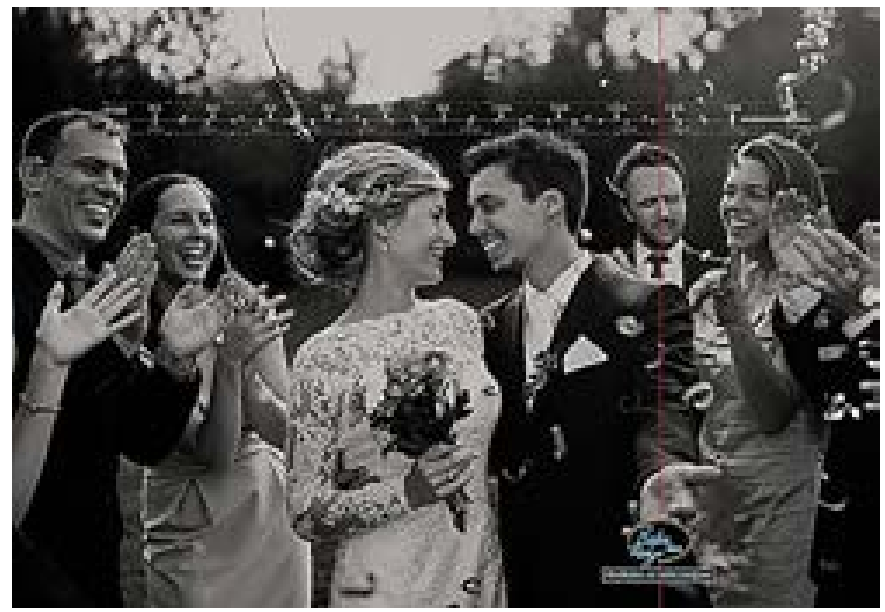

Fotoğraf 6. Baba Radyo Reklamı 
Ödül alan Baba Radyo reklamı incelendiğinde; "Arabeskin en baba radyosu” metnini görmekteyiz. Radyo frekansının ve arabesk müzik dalının babaya benzetilmesi yoluyla ontolojik metafor kullanılmıştır. Baba radyo söyleminin zaten metaforik bir anlatım olmasının yanında reklam görselinde, mutlu anlardan biri olan evlilik töreni anlık fotoğrafı bulunmaktadır. Baba radyo frekansının bulunduğu yerde dikkat çeken bir kişi bulunmaktadır. Bu kişi Baba Radyonun frekansının hangi tür müzik ile yayın yaptığı ile ilgili fikir veren mimikler içerisindedir. Bu haliyle Baba Radyo, tüm diğer frekanslardaki radyolar eğlenceli müzik yayını yaparken, kendilerinin daha duygusal ve arabesk müzik tarzında yayın yaptığını göstermektedir. Sadece bir görsel ile bunun izleyici veya tüketiciye aktarılması ancak böyle bir metaforik anlatımla mümkün olabilirdi. Bu haliyle Baba Radyo yöneticileri kendi alanlarını hedef kitlelerine aktarmışlardır. Reklam mesajını alan hedef kitle, kendisini Baba Radyo frekansının kırımızı dikey çizgi ile dikkat çekildiği kişinin yerine koyacak, zihinsel karar verme sürecini bu haliye işletecektir. Baba Radyo yöneticileri de mesajı alan hedef kitlenin tepkilerini eğer ölçerse, radyo imajını sağlamlaştırma olanacağı bulabilecektir.

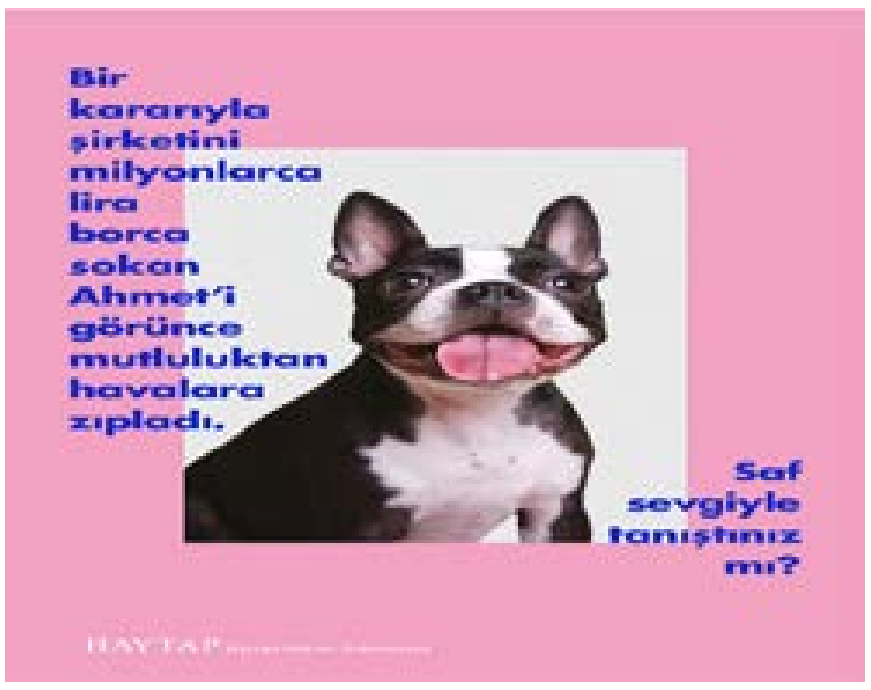

Fotoğraf 7. Haytap (Hayvan Hakları Federasyonu) Reklamı

Ödül alan Haytap (Hayvan Hakları Federasyonu)'ın reklam görseli incelendiğinde; bir köpek fotoğrafı görülmektedir. Reklam metninde "Bir kararıyla şirketini milyonlarca lira borca sokan Ahmet'i görünce mutluluktan havalara zıpladi. Saf sevgiyle tanıştınız mı? “ cümleleri ile karşılaşmaktayız. Havalara zıplaması anlatımı ile yön metaforu kullanılırken köpek sevgisinin saf sevgiye benzetilmesi yoluyla da yapı metaforu kullanılmıştır.

Hayvanseverlerin oldukça dikkatini çeken bu reklamda yapı metaforunun kullanılmasının yanında dikkat çeken bir ayrıntı olarak mutlu bir köpek fotoğrafının görülmesidir. Ayrıca reklamda hayvan sevgisi ile insan sevgisi arasındaki fark, dolaylı 
olarak aktarılmaya çalışılmıştır. İnsan sevgisi ile hayvan sevgisinin birbirinden oldukça farklı olduğu, reklamda yer alan metinde açıkça ifade edilmektedir. Fazlasıyla mutlu, heyecanlı ve canlı görünen bir hayvan görselinin yer alması, reklam metninde bahsi geçen konuda insanların tam tersine bir tepki verdiği gerçeği gözler önüne serilmektedir.

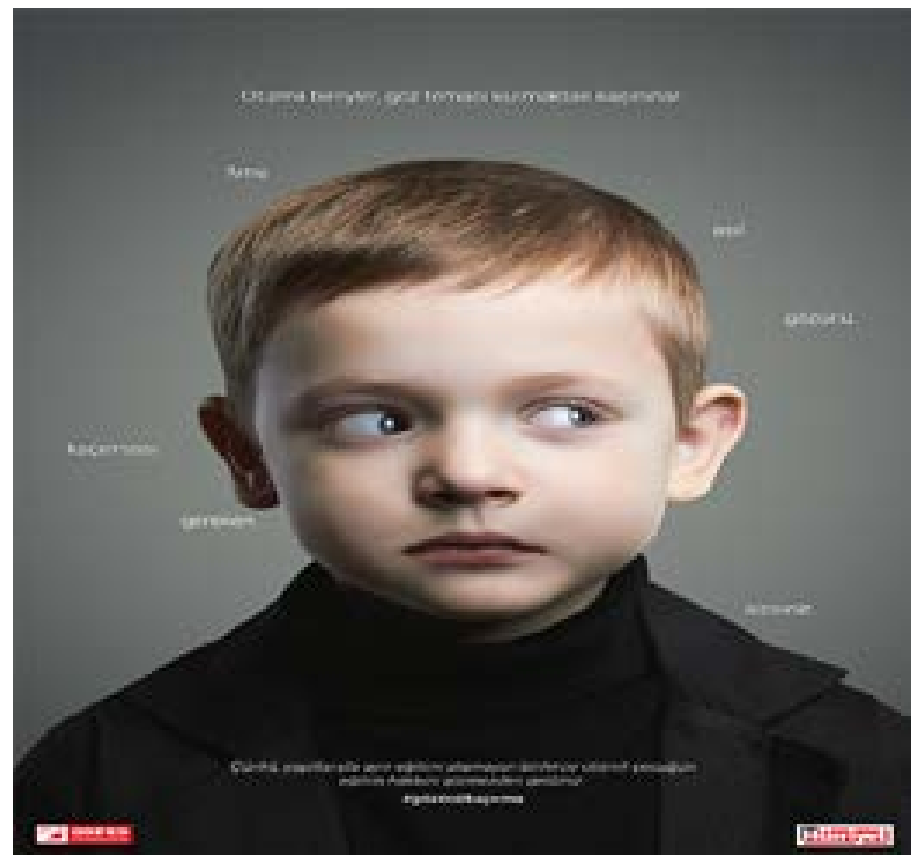

Fotoğraf 8. Odfed Reklam1-1

Ödül alan ODFED (Otizm Dernekleri Federasyonu) reklamı incelendiğinde; "Otizmli bireyler, göz teması kurmaktan kaçınırlar. Ama asıl gözünü kaçırması gereken sizsiniz. Çünkü yaşıtlarıla aynı eğitimi alamayan binlerce otizmli çocuğun eğitim hakkını görmezden geldiniz." Reklam metninin en çarpıcı cümlesi olan "Ama asıl gözünü kaçırması gereken sizsiziz" cümlesinde yön metaforu kullanılarak ifade vurucu hale getirilmiştir. Görseldeki erkek çocuğunun gözünü kaçırması da yön metaforunu desteklemiştir. Reklam görseli çalışmanın kapsamında incelendiğinde; izleyicinin dikkatini çekmek için yapılan sosyal sorumluluk ve farkındalık çalışması olarak görülebilir. 


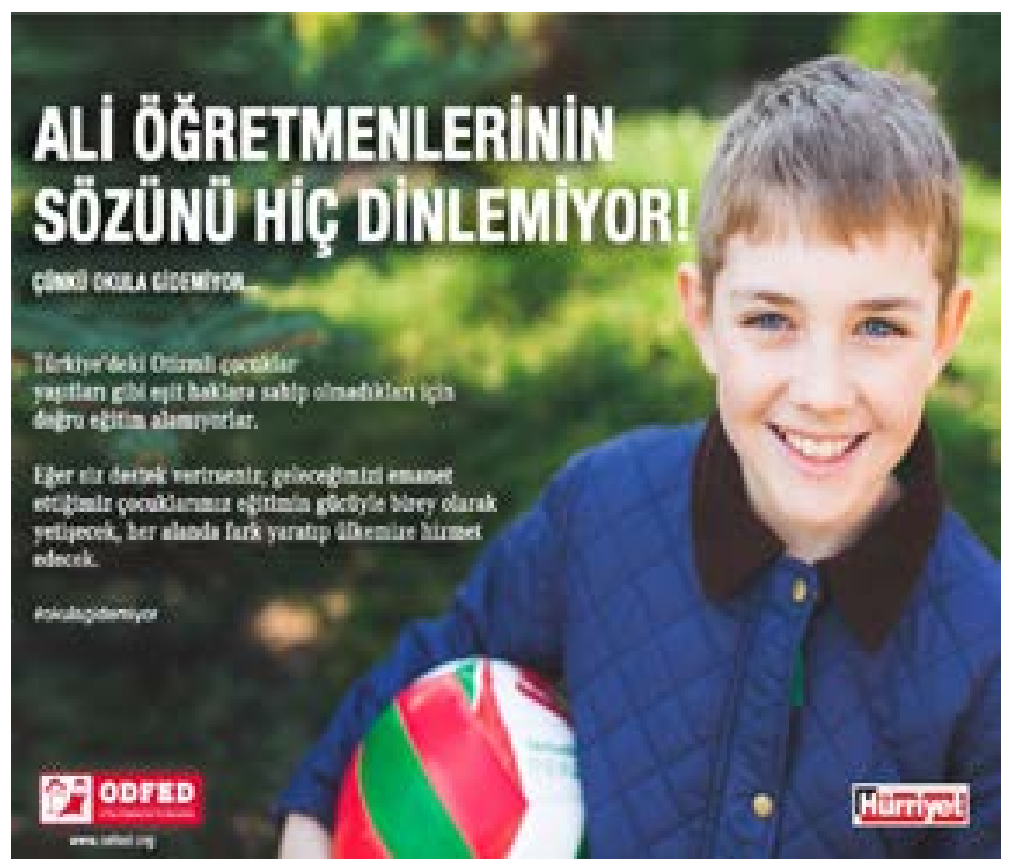

Fotoğraf 9. Odfed Reklamı-2

Ödül alan ODFED reklamı incelendiğinde; reklam metni "Ali öğretmenlerinin sözünü hiç dinlemiyor! Çünkü okula gidemiyor. Türkiye' deki Otizmli çocuklar yaşıtları gibi eşit haklara sahip olamadıkları için doğru eğitim alamıyorlar. Eğer siz destek verirseniz; geleceğimizi emanet ettiğimiz çocuklarımız eğitimin gücüyle birey olarak yetişecek, her alanda fark yaratıp ülkemize hizmet edecek" cümlelerinden oluşmaktadır.

Geleceği çocuklara emanet etme cümlesiyle gelecek emanet edilecek bir nesneye benzetilmesiyle yapı metaforu kullanılmıştır. Ayrıca cümlenin devamında yer alan eğitimin gücü söylemi ontolojik metaforun kullanıldığını göstermektedir. Reklamda yer alan görsel ile reklam metninin birbirine karşıt olduğu açıkça görülebilmektedir. Sevimli ve sakin olduğu algısını yaratan erkek çocuğunun öğretmenlerinin sözünü dinlemediği sözü ile dikkat çekilmiştir. Bu reklam görseline bakan ve ardından reklam metninin ilk cümlesini okuyan izleyici bu tezatlığın ne olduğunu merak ederek okumaya devam edecek, böylelikle izleyicinin dikkati reklam metni içeriğine kaydırılacaktır. Metin içeriği metafor içeren cümleler ile doludur. Reklamın izleyici ile buluşmasının ardından yapılan bir tepki araştırması, sosyal sorumluluk faaliyetiyle yer alan ODFED markasını zihinlerde bir yere oturtacaktır. Bu haliyle yine marka yöneticileri veya marka yöneticileri ile birlikte çalışan reklamcılar tüketicilerin metafor yoluyla yönlendirmeyi başarabileceklerdir. 


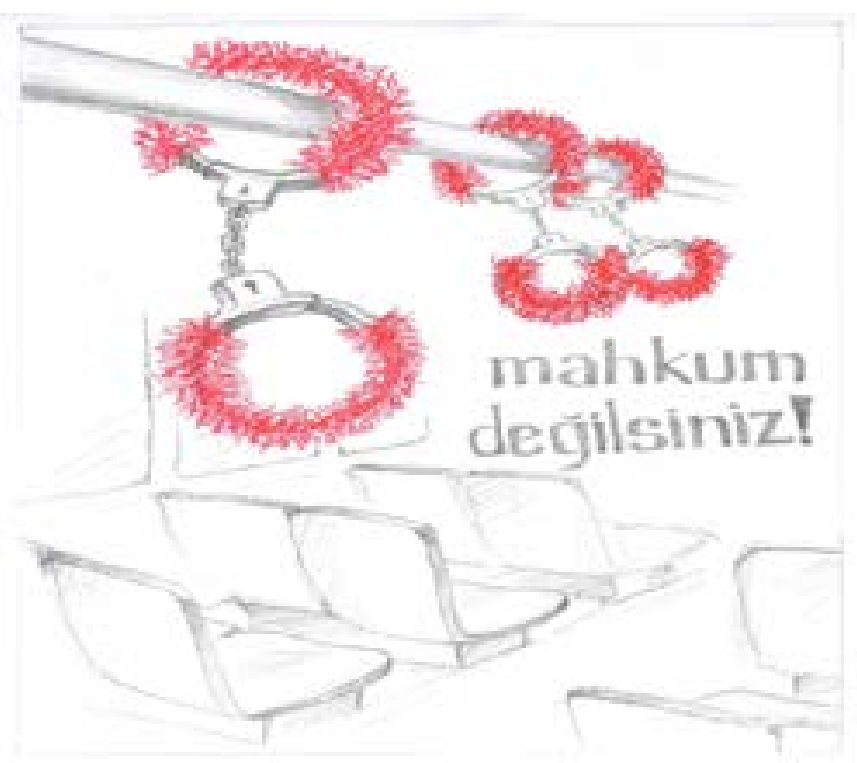

Fotoğraf 10. Markasız Reklam- Canlı Kırmızı

Marka yer almayan ve canlı kırmızı kategorisinde ödül alan yukarıdaki reklam metninde "Mahkum değilsiniz!" cümlesi yer almaktadır. Kelepçe görseli ile desteklenen reklamda otobüslerde yer alan tutacakların kelepçeye benzetilmesi yoluyla yapı metaforu kullanılmıştır. Oldukça dikkat çeken bu reklamda yer alan görsel zaten başlı başına metaforik bir görseldir. Kelepçenin mahkumlar için kullanıldığı, otobüs tutacaklarının da mahkumiyet ile ilgisi olduğunu anlatmaya çalışmaktadır. Hem otobüs ile seyahat etmeye mahkum olmama, hem de mahkumlarda kullanılan kelepçelerin otobüs tutacaklarına benzetilmesi yoluyla metafor kullanılmıştır. $\mathrm{Bu}$ haliyle bakıldığında; otomobil markalarının rahatlıkla kullanabilecekleri bir reklam olduğu söylenebilir.

\section{SONUÇ}

Günümüzde rekabetin hızla arttı̆g 1 bilinen bir gerçektir. Markaların bu rekabet ortamında tüketicilerin zihinsel süreçlerine dâhil olmaları markalar için büyük bir avantaj sağlayacağı düşünülmektedir. Dilin ve sözcüklerin yanı sıra metaforlar ile dünyayı anlama ve anlatmanın antik çağlardan beri gerçekleştirildiği bir gerçektir. Metaforu sadece dil ve sözcüklerden oluşan bir yapı olarak değil aynı zamanda düşünsel ve bilişsel boyutuyla değerlendirmek gerekmektedir. Deneyimlerden elde edilenlerin metaforlar yoluyla soyut halde kavramsal sisteme yerleştirildiği bilinmekte, bu haliyle tüketici kavramsal düşünce mekanizmasının müdahalesi söz konusu olabilmektedir. Metafor zihinsel süreçler söz konusu olduğunda, örtük düşünceler bir adım öteye geçerek, var olan anlamlar üzerine ek anlamlar yüklenmeye başlar. Böyle bir gücün pazarlama alanında yöneticiler tarafından kullanılması te- 
sadüf değildir. Mills (1977) 'in tanımıyla “sosyolojik düş gücü” metaforlar aracilığı ile geliştirilebilir.

Metafor yoluyla toplumların zihinsel süreçlerini yönetebildiğimiz bilinirken markaların bu zihinsel süreçleri yönetme eyleminde pasif kalmasının mümkün olmadığı bir gerçektir. İlgili bölümde de bahsedildiği üzere; markaların tüketici zihinlerini okuma süreçleri reklamlara karşı verdikleri tepki üzerinden de ölçülebileceği görülmektedir. Bu anlamda her yıl düzenlenen Jüri Başkanlığını Faika Ergüder'in üstlendiği Kırmızı Reklam Ödülleri reklamlarının 2016 yılında "Kırmızı" ödülü olan en önemli ödülün sahibi olan reklamlar çalışma kapsamına alınmıştır.

Kırmızı reklam ödülleri reklamda yaratıcılığa, başarıya ödül veren bir yarışmadır. Kırmızı Ödülleri, sadece gazete ve dergi reklamlarının katıldığı bir yarışma olması sebebiyle ülkemizde bir ilk. Dünyada Kırmızı gibi sadece basın reklamları arasında düzenlenen yarışmalara daha sık rastlamak mümkün. Örneğin, Amerika Birleşik Devletleri'nde Newspaper Association of America - NAA tarafindan düzenlenen ATHENA isimli yarışma sadece gazete reklamlarının katılımına açık. İngiltere'de ünlü reklamcılık dergisi Campaign, salt basın reklamları yarışması düzenliyor. Yine Amerika'da The New York Festivals tarafindan basın reklamları için düzenlenen bir yarışma bulunuyor (Kırmızı, 2017).

Ödül alan her bir reklam için ayrı ayrı metafor değerlendirmesi yapılmış ve ödül alan reklamlarda mutlaka metafor kullanıldığı ortaya konulmuştur. Metafor kullanarak tüketicilerin dikkatinin çekildiği düşünülmektedir. Markalara metaforik yaklaşım sadece bir sonuç değil, tüketimi anlamlandırma ve yorumlamada çok boyutlu ve kültürel farklılıkları da dikkate alan bir araç olarak da görülebilir (Chelminski ve Ekin, 2007: 8). Markaların kendi reklamlarını yaparken metaforik anlatım veya metaforik görsel kullanımı ile tüketicilere erişimde ve tüketicileri anlamada kolaylık sağlayacağ 1 düşünülmektedir. Tüketicileri anlayan marka yöneticileri, tüketici zihinsel süreçlerine dahil olan kişiler olarak düşünülmelidir. Tüketicilerin karar verme süreçlerinin karmaşıklığ 1 ve anlık değişimlerle dolu olduğu bilinen bir gerçektir. Fakat kişilerin zihin haritalarına ulaşıldıkça, bireylerin kararlarında genel olarak marjinal değişiklik olmadığı görülecektir.

Bu çalışmada elde edilen bulgular, Kırmızı Reklam Ödülleri yarışmasında ödül alan reklamların her birinde metafor kullanıldığını göstermektedir. Bu durum, her şeyden önce jüri üyelerinin beğenisini açıklayan bir bulgudur. Tüketicilerin etkilenmesi konusunda bilgilendirme sağlamamaktadır. Fakat metafor kullanımının tüketiciyi etkilediği yönündeki bulgulara sahip olan araştırmalar (Karamehmet, 2012) incelendiğinde metafor kullanılan reklamların tüketiciler üzerinde etkili olduğu sonucu net ve anlaşılır şekilde görülebilmektedir.

Tüketicilerin zihinsel süreçlerine dahil olan markaların veri tabanlarını müşterilerin araştırılan bu profilleri ile güncellemeleri gerekmektedir. Çalışmanın pazarlama alanındaki metafor ile ilgili yapılacak ileriki araştırmalar için kaynak oluşturması beklenmektedir. 


\section{KAYNAKÇA}

\section{Kitap}

BALL, Michael, S. ve SMITH, Gregory, W., H. (1992). Analyzing Visual Data. Qualitative Research Methods Series A Sage University Paper. London Volume 24.

BLACK, Max (1993). More About Metaphor. Metaphor and Thought, 2nd ed., Çev. Andrew Ortony. Cambridge Univ. Press.

ENTIN, Alan, D. (1981). The Use of Photographs and Family Albums in Family Therapy. In Questions and Answers in the Practice of Family Therapy, A. GURMAN, ed. New York, NY: Brunner Mazel.

FİLIZOK, Rıza (2001). Anlam Analizine Giriş, İzmir, Ege Üniversitesi Edebiyat Fakültesi Yayınları.

FORCEVILLE, Charles (1996). Pictorial Metaphor in Advertising, London: Routledge.

GOATLY, Andrew (1997). The Language of Metaphor: London: Routledge.

KARAMEHMET, Bilge (2012). Kuramsal İletişimde Metafor, Beta Yayınevi.

KORO-LJUNGBERG, Mirka (2001), Metaphors As a Way to Explore Qualitative Data, Qualitative Studies in Education, 14(3), 367-379.

KOSSLYN, Stephen, Michael and KOENIG, Olivier (1992). Wet Mind: The New Cognitive Neuroscience, NY: The Free Press.

KRAUSS, David, A., and FRYREAR, Jerry, L. (1971). Phototherapy in Mental Health. Springfield, IL: Charles C. Thomas.

LAKOFF, George ve JOHNSON, Mark (2005). Metaforlar: hayat, anlam ve dil, Çeviren: Gökhan Yavuz Demir, İstanbul Paradigma Yayınları.

LAKOFF, George (1993). The Contemporary Theory of Metaphor. A. Ortony (Ed.), Metaphor and Thought. Second Edition. Cambridge: Cambridge University Press.

LAKOFF, George ve JOHNSON, Mark (1980). Metaphors We Live By. Chicago: The University of Chicago Press.

LAKOFF, George ve JOHNSON, Mark (2003). Metaphors We Live By. İkinci Bask1. Chicago: University Of Chicago Press.

MILLS, Wright, C. (1977). L'İmaginationSociologique, François Maspero, Paris. (Toplumbilimsel Düşün), (Çev: Ünsal Oskay), Der Yayınları, İstanbul, 2000.

MOISANDER, Johanna ve VALTONEN, Anu (2006). Qualitative Marketing Research - A Cultural Approach, London: Sage Publications.

PHILLIPS, Nelson ve HARDY, Cynthia (2002), Discourse Analysis, Sage Publications, USA. 
ROSCH, Eleanor (1978). Principles of Categorization, First publised in: Rosch, Eleanor and Lloyd, Barbara B. (eds), Cognition and categorization 27-48. Hillsdale, NJ: Lawrence Erlbaum.

\section{Kitap Bölümü}

BIEL, Alexander, L. (1993). Converting Image into Equity, in Brand Equity and Advertising: Advertising's Role in Building Strong Brands, David A. Aaker and Alexander Biel (editors), pp. 67-82, Hilsdale, NJ: Lawrence Erlbaum Associates.

CHELMINSKI, Piotr ve EKİN, A., Cemal (2007). Ethnographic Research in Marketing: Methods and Implications, Third International Conference on Business, Management and Economics, Selected Proceedings - Perspectives on Business and Management, Eds., C. Can Aktan ve Sabah Balta, Vol. 2, 1-10.

COULTER, Robin, Higie and ZALTMAN, Gerald (1994). Using the Zaltman Metaphor Elicitation Technique to Understand Brand Images, in NA - Advances in Consumer Research Volume 21, eds. Chris T. Allen and Deborah Roedder John, Provo, UT : Association for Consumer Research, Pages: 501-507.

GIBBS, Graham (1999). Using Assessment Strategically to Change the Way Students Learn. Brown, Sally ve Glasner, Angela (eds) Assessment Matters in Higher Education, Buckingham: SRHE and the Open University Press.

JOHNSON, Steven (1997). Interface Culture: How New Technology Transforms The Way We Create \& Communicate ? New York: Basic Book.

LUTZ, Kathy, A. ve LUTZ, Richard, J. (1978). Imagery-Eliciting Strategies: Review and Implications of Research", in NA - Advances in Consumer Research Volume 05, eds. Kent Hunt, Ann Abor, MI : Association for Consumer Research, Pages: 611-620.

MACINNIS, Deborah, J. ve PRICE, Linda (1990). An Exploratory Study of the Effects of Imagery Processing and Consumer Experience on Expectations and Satisfaction, in NA - Advances in Consumer Research Volume 17, eds. Marvin E. Goldberg, Gerald Gorn, and Richard W. Pollay, Provo, UT : Association for Consumer Research, 41-47.

ROSSITER, John, R. (1982). Visual Imagery: Applications to Advertising, in NA Advances in Consumer Research Volume 09, eds. Andrew Mitchell, Ann Abor, MI : Association for Consumer Research, 101-106.

ROSSITER, John, R ve PERCY, Larry (1978). Visual Imaging Ability As a Mediator of Advertising Response, in NA - Advances in Consumer Research Volume 05, eds. Kent Hunt, Ann Abor, MI : Association for Consumer Research, 621-629.

WEISNER, Thomas, S. (1988). Socialization for Parenthood in Sibling Caretaking Societies. In Parenting Across the Life Span. Jane Lancaster, Alice Rossi and Jeanne Altmann,Eds. New York: Aldin Press. 237-270 


\section{Tez (Doktora ya da Yüksek Lisans)Alıntıları}

CONDON, C. (1999). A Semiotic Approach to the Use Of Metaphor In Human Computer Interface: Yayımlanmamış Doktora Tezi. İngiltere: Brunel University. http://bura.brunel.ac.uk/bitstream/2438/4800/1/FulltextThesis.pdf (14 Aral1k 2017)

\section{Bildiri}

SIRAJ-BLATCHFORD, John (1995). Kelly's Repertory Grid: A Technique for Developing Evaluation in Design and Technology. IDATER 1995 Conference, Loughborough: Loughborough University

\section{Bilimsel Dergide Makale}

ALTUNAY, Esen., ORAL, Gülşin ve YALÇINKAYA, Münevver (2014). Eğitim Kurumlarında Mobbing Uygulamalarına İlişkin Nitel Bir Araştırma, Sakarya University Journal of Education, 4 (1): 62-80.

ARSLAN, Metin ve BAYRAKCI, Mustafa (2006). Metaforik Düşünme ve Öğrenme Yaklaşımının Eğitim Öğretim Açısından İncelenmesi, Milli Eğitim Dergisi, 171: 100-108

BONE, P., F. ve ELLEN P., S. (1992). The Generation and Consequences of Communication-Evoked Imagery, Journal of Consumer Research, 19 (June), 93-104.

CARROLL, J., M. ve MACK, R., L. (1999). Metaphor, Computing Systems, and Active Learning. International Journal of Human-Computer Studie: 51, 385-403.

ÇINAR, Bekir. (2008). “Teşbih (Benzetme) Sanatına Dilbilimsel Bir Yaklaşım”, Modern Türklük Araştırmaları Dergisi, (1) 5, Ankara.

EL REFAIE, Elisabeth (2003). Understanding Visual Metaphor: The Example of Newspaper Cartoons. Visual Communication Vol 2(1): 75-95.

ERDEM, Ferda ve SARVAN, Fulya (2001). Akademik Örgütlerde Rehberlik İlişkilerinin Metaforlarla Analizi, Yönetim Araştırmaları Dergisi, cilt.1, 1-10.

GÜNEŞ, Aysun ve FIRAT, Mehmet (2016). Açık ve Uzaktan Öğrenmede Metafor Analizi Araştırmaları. Açıköğretim Uygulamaları ve Araştırmaları Dergisi. 2(3). 115-129.

JAKOBSON, Roman (2003) “Metaforik ve Metonimik Kutuplar”, Çev. E. Efe Çakmak, Kitap-lık, İstanbul : Yapı Kredi Yay., Sayı: 65.

KRIPPENDORFF, Klaus (1993). The Past of Communication's Hoped-For Future. Journal of Communication, 43(3)., 34-37

LEVINE, Phoebe, M. (2005). Metaphors and Image of Classrooms. Kappa Delta Pi Record. Summer. 41(4). 172-175. 
LODGE, David (2003). Eğretileme ve Düzdeğişmece, Çev. Mehmet H. Doğan, Kitap-lık, İstanbul: Yapı Kredi Yay., (65).

MILLER, Steven, I. (1987). "Some Comments on the Utility of Metaphors for Educational Theory and Practice", Educational Theory, 37, 219-227.Morgan, E. ve Reichert, T. (1999). The Message is in the Metaphor: Assessing the Comprehension of Metaphors in Advertisements, Journal of Advertising, 28(4).

PERCY, Larry ve ROSSTTER, John, R. (1992). A Model of Brand Awareness and Brand Attitude Advertising Strategies, Psychology ve Marketing, (Jul/Aug), 9(4), 263-274.

SALMAN, Yurdanur (2003). Dilin Düşevreni: Eğretileme. Kitap-lık, Yap1 Kredi Yayınları Aylık Edebiyat Dergisi. 65, 53-54.

SEITZ, Jay, A. (1998). "Nonverbal Metaphor: A Review of Theories and Evidence" Genetic, Social and General Psychology Monographs. Vol: 124, No: 1, Sayfa: 95-119

ŞEYİHOĞLU, Ayşegül ve GENÇER, Gülşah (2011). Hayat Bilgisi Öğretiminde “Metafor” Tekniğinin Kullanımı. Türk Fen Eğitimi Dergisi. 8(3).

SCHMITT, Rudolph (2005), Systematic Metaphor Analysis As a Method of Qualitative Research, The Qualitative Report, 10 (2), 358-394.

THIBODEAU, Paul. H. (2016). Extended Metaphors are the Home Runs of Persuasion: Don't Fumble the Phrase. Metaphor and Symbol, 31(2), 53-72.

TORLAK, Ömer (2008). Tüketici Davranışını Anlamada Metafor Kullanımı: Postmodern Tüketiciyi "Sivil İtaatsizlik" Metaforu ile Açıklamak. Pazarlama ve Pazarlama Araştırmaları Dergisi. (2). 63-76.

\section{İnternetten yayınlananan dergide makale}

AKŞEHİRLİ, Soner. (2005). "Çağdaş Metafor Teorisi”, Ege Edebiyat, Kaynak: http://www.ege-edebiyat.org/modules.php? name=Downloads\&d_op=getit\&lid=111 , Erişim Tarihi: 14.12.2017

CHANDRA, Shruti (2009). "18 Types of Metaphors", Ezine Articles, Kaynak: http://ezinearticles.com/?18-Types-of-Metaphors\&id=3305146 , Erişim Tarihi: 14.12.2017

NORTHQUIST, Richard (2017). “The Different Types of Metaphors”. Thought Co, Kaynak: https://www.thoughtco.com/ways-of-looking-at-a-metaphor-1691815 , Erişim Tarihi: 14.12 .2017

PINK, Daniel, H. (1998). "Metaphor Marketing”. Fast Company, Kaynak: https:// www.fastcompany.com/33672/metaphor-marketing, (Erişim Tarihi: 04.12.2017) 


\section{Web Sitesi}

KIRMIZI ÖDÜLLERİ (2016). Basında En İyiler Diğer Kategorisi, http://kirmiziodulleri.com/Kazananlar2.aspx?tip=ka\&od=kip\&odid=79\&ki=494\&katilimi$\mathrm{d}=7944 \& \mathrm{id}=76 \mathrm{~d} 26069-8554-4 \mathrm{eff}-\mathrm{a}$ dd-25219649b1ba, (Erişim Tarihi: 04.12.2017) KIRMIZI ÖDÜLLERİ (2016). Basında En İyi Sosyal İçerikli Reklam, http://kirmiziodulleri.com/Kazananlar2 aspx?tip=ka\&od=jur\&odid $=79 \& \mathrm{ki}=498 \&$ katilimi$\mathrm{d}=8168 \& \mathrm{id}=1 \mathrm{f} 2 \mathrm{ddda} 0-\mathrm{b} 71 \mathrm{e}-4894-\mathrm{bfe} 7-4 \mathrm{e} 153 \mathrm{cdf1349}$, (Erişim Tarihi: 04.12.2017)

KIRMIZI ÖDÜLLERİ (2016). Basında En İyi Dayanıklı Tüketim Ürünü Reklamı, http://kirmiziodulleri.com/Kazananlar2.aspx?tip=ka\&odid=79\&ki=490\&katilimi$\mathrm{d}=7948 \& \mathrm{id}=391 \mathrm{c} 3199-55 \mathrm{dc}-46 \mathrm{ae}-\mathrm{afd} 6-129221 \mathrm{db} 3758$, (Erişim Tarihi: 04.12.2017) KIRMIZI ÖDÜLLERİ (2016). Basında Hızlı Tüketim Ürünü, http://kirmiziodulleri.com/Kazananlar2 aspx?tip $=$ ka\&odid $=79 \& \mathrm{ki}=491 \&$ katilimid $=7219 \& \mathrm{id}=-$ f888ea55-2184-4bd2-8e26-296ac51a2000, (Erişim Tarihi: 04.12.2017)

KIRMIZI ÖDÜLLERİ (2016). Hizmet, , http://kirmiziodulleri.com/Kazananlar2. aspx tip $=$ ka\&odid $=79 \& \mathrm{ki}=492 \&$ katilimid $=7739 \& \mathrm{id}=$ fcff5a $4 \mathrm{~d}-f 9 \mathrm{e} 6-44 \mathrm{ac}-9 \mathrm{e}-$ ed-1f6c4c821b40, (Erişim Tarihi: 04.12.2017)

KIRMIZI ÖDÜLLERİ (2016). Basında En İyi Kültür, Sanat Ve Eğlence Reklam1, http://kirmiziodulleri.com/Kazananlar2.aspx?tip=ka\&odid=79\&ki=493\&katilimid=7998\&id=d16a3a0d-37cd-4d73-b6d0-490d5768e3fb, (Erişim Tarihi: $04.12 .2017)$

KIRMIZI ÖDÜLLERİ (2016). Basında En İyi Sosyal İçerikli Reklamhttp://kirmiziodulleri.com/Kazananlar2 aspx?tip $=$ ka\&odid $=79 \&$ ki $=498 \&$ katilimid $=8125 \&$ i$\mathrm{d}=46107592-658 \mathrm{~d}-4133-a 35 f-b 368 \mathrm{c} 4 d 9 d f d 3$, (Erişim Tarihi: 04.12.2017)

KIRMIZI ÖDÜLLERI (2016). Hürriyet Özel Ödülü, http://kirmiziodulleri.com/Kazananlar2 aspx?tip $=$ ka\&odid $=79 \& \mathrm{ki}=502 \&$ katilimid $=8229 \& \mathrm{id}=-$ 7bf771cc-89b9-4f14-9aa1-03cb828f8741, (Erişim Tarihi: 04.12.2017)

KIRMIZI ÖDÜLLERI (2016). Hürriyet Özel Ödülü, http://kirmiziodulleri. $\mathrm{com} /$ Kazananlar2 asp $x$ tip $=$ ka\& odid $=79 \& \mathrm{ki}=502 \& \mathrm{katilimid}=8226 \& \mathrm{id}=55 \mathrm{~d}-$ bf4cb-c074-4f4a-b209-cb6507c01eb2, (Erişim Tarihi: 04.12.2017)

KIRMIZI ÖDÜLLERİ (2016). Canlı Kırmız1, http://kirmiziodulleri.com/Kazananlar2 .aspx?tip=ka\&odid $=79 \& \mathrm{ki}=504 \&$ katilimid $=8276 \& \mathrm{id}=\mathrm{a} 875 \mathrm{fbea}-0 \mathrm{~d} 0 \mathrm{~d}-44 \mathrm{a} 0-92$ cb-7bb479c71867, (Erişim Tarihi: 04.12.2017)

İnternet Kaynağ 1

KIRMIZI (2017). http://kirmiziodulleri.com/Hakkimizda.aspx, (Erişim Tarihi: 21.12.2017) 
